\title{
Supplementary publication
}

References used to provide thermal histories for the data set.

Andreissen, P.A.M., and Zeck, H.P., 1996, Fission-track constraints on timing of Alpine nappe emplacement and rates of cooling and exhumation, Torrox area, Betic Cordilleras, Spain: Chemical Geology v.131, 199-206.

Armstrong, P.A., Ehlers, T.A., Chapman, D.S., Farley, K.A., and Kamp, P.J.J.,. 2003, Exhumation of the central Wasatch Mountains, Utah: 1. Patterns and timing of exhumation deduced from low-temperature thermochronology data: Journal of Geophysical Research, v.108, a2172.

Arne, D., Worley, B., Wilson, C., Chen, S.F., Foster, D., Luo, Z.L., Lui, S.G., and Dirks, P., 1997, Differential exhumation in response to episodic thrusting along the eastern margin of the Tibetan Plateau. Tectonophysics: v.280, 239-256.

Arne, D.C., Zentilli, M., Grist, A.M., and Collins, M., 1998, Constraints on the timing of thrusting during the Eurekan orogeny, Canadian Arctic archipeligo: an integrated approach to thermal history analysis: Canadian Journal of Earth Sciences, v.35, 30-38.

Biermeier, C., Wiesinger, M., Stüwe, K., Foster, D.A., Gibson, H.J., and Raza, A., 2003, Aspects of the structural and late thermal evolution of the Redbank Thrust system, central Australia: constraints from the Speares Metamorphics: Australian Journal of Earth Sciences, v.50, 983-999.

Blackmer, G.C., Omar, G.I., and Gold, D.P., 1994, Post-Alleghanian unroofing history of the Appalachian Basin, Pennsylvania, from apatite fission track analysis and thermal models: Tectonics, v.13, 1259-1276. Blythe, A.E., and Kleinspehn, K.L., 1998, Tectonically versus climatically driven Cenozoic exhumation of the Eurasian plate margin, Svalbard: Fission track analyses: Tectonics, v.17, 621-639.

Blythe, A.E., Murphy, J., and O'Sullivan, P.B., 1997, Tertiary cooling and deformation in the south-central Brooks Range: Evidence from zircon and apatite fission-track analyses: Journal of Geology, v.105, 583599.

Boettcher, S.S., and Milliken, K.L., 1994, Mesozoic-Cenozoic unroofing of the southern Appalachian basin: Apatite fission track evidence from Middle Pennsylvanian sandstones: Journal of Geology, v.102, 655-663.

Bojar, A-V., Neubauer, F., and Fritz, H., 1998, Cretaceous to Cenozoic thermal evolution of the southwestern South Carpathians: evidence from fission-track thermochronology: Tectonophysics, v.297, 229-249.

Boztu, D., Jonckheere, R., Wagner, G.A., and Yeingil, Z., 2004, Slow Senonian and fast Palaeocene-Early Eocene uplift of the granitoids in the Central Eastern Pontides, Turkey: apatite fission-track results: Tectonophysics, v.382, 213-228.

Brown, R.W., Summerfield, M.A., and Gleadow, A.J.W., 2002, Denudational history along a transect across the Drakensburg Escarpment of southern Africa derived from apatite fission track thermochronology: Journal of Geophysical Research, v.107, a2333.

Cederbom, C., Larson, S., Tullborg, E., and Stiberg, J., 2000, Fission track thermochronology applied to Phanerozoic thermotectonic events in central and southern Sweden: Tectonophysics, v.316, 153-167. Clift, P.D., Carter, A., and Hurford, A.J., 1998, The erosional and uplift history of NE Atlantic passive margins: constraints on a passing plume: Journal of the Geological Society of London, v.155, 787-800. de Bruijne, C.H., and Andriessen, P.A.M., 2002, Far field effects of Alpine plate tectonism in the Iberian microplate recorded by fault-related denudation in the Spanish Central System: Tectonophysics, v.349, 161-184.

De Borba, A.W., Vignol-Lelarge, M.L.M., Mizusaki, A.M.P., 2002, Uplift and denudation of the Caçapava do Sul granitoids (southern Brazil) during Late Paleozoic and Mesozoic: constraints from apatite fissiontrack data: Journal of South American Earth Sciences, v.15, 683-692.

De Grave, J., and Van den haute, P., 2002, Denudation and cooling of the Lake Teletskoye Region in the Altai Mountains (South Siberia) as revealed by apatite fission-track thermochronology: Tectonophysics, v.349, 145-159.

Emmel, B., Jacobs, J., Razakamanaana, T., 2004, Titanite and apatite fission track analyses on basement rocks of central-southern Madagascar: constraints on exhumation and denudation rates along the eastern rift shoulder of the Morondava basin: Journal of African Earth Sciences, v.38, 343-361.

England, T.D.J., Currie, L.D., Massey, N.D.W., Roden-Tice, M.K., and Miller, D.S., 1997: Apatite fission track dating of the Cowichan fold and thrust system, southern Vancouver island, British Columbia:

Canadian Journal of Earth Sciences, v.34, 635-645. 
Fayon, A.K., Peacock, S.M., Stump, E., and Reynolds, S.J., 2000: Fission track analysis of the footwall of the Catalina detachment fault, Arizona: Tectonic denudation, magmatism and erosion: Journal of Geophysical Research, v.105, 11047-11062.

Foster, D.A., and Gleadow, A.J.W., 1996, Structural framework and denudation history of the flanks of the Kenya and Anza Rifts, East Africa: Tectonics, v.15, 258-271.

Fügenschuh, B., Mancktelow, N.S., and Seward, D., 2000, Cretaceous to Neogene cooling and exhumation history of the Oetztal-Stubai basement complex, eastern Alps: A structural and fission track study:

Tectonics, v.19, 905-918.

Fügenschuh, B., and Schmid, S.M., 2003, Late stages of deformation and exhumation of an orogen constrained by fission-track data: A case study in the Western Alps: Bulletin of the Geological Society of America, v.115, 1425-1440.

Gallagher, K., Hawkesworth, C.J., and Mantovani, M.S.M., 1994, The denudation history of the onshore continental margin of SE Brazil inferred from apatite fission track data: Journal of Geophysical Research, v.99, 18117-18145.

Gleadow, A.J.W., Kohn, B.P., Brown, R.W., O'Sullivan, P.B., and Raza, A., 2002, Fission track thermotectonic imaging of the Australian continent: Tectonophysics, v.349, 5-21.

Gunnell, Y., 2000, Apatite fission track thermochronology: an overview of its potential and limitations in geomorphology: Basin Research, v.12, 115-132.

Hansen, K., Bergman, S.C., and Henk, B., 2001, The Jameson Land basin (east Greenland): a fission track study of the tectonic and thermal evolution in the Cenozoic North Atlantic spreading regime:

Tectonophysics, v.331, 307-339.

Harman, R., Gallagher, K., Brown, R., Raza, A., Bizzi, L., 1998, Accelerated denudation and tectonic/geomorphic reactivation of cratons of northeastern Brazil during the late Cretaceous: Journal of Geophysical Research, v.103, 27091-27105.

Hejl, E., Coyle, D., Lal, N., Van den Haute, P., Wagner, G.A., 1997, Fission-track dating of the western border of the Bohemian massif: thermochronology and tectonic implications: Geologische Rundschau, v.86, 210-219.

Hejl, E., Riedl, H., Weingartner, H., 2002, Post-plutonic unroofing and morphogenesis of the AtticCycladic complex (Aegea, Greece): Tectonophysics, v.349, 37-56.

House, M.A., Kelley, S.A., and Roy, M., 2003, Refining the footwall cooling history of a rift flank uplift, Rio Grande rift, New Mexico: Tectonics, v.22, a1029.

House, M.A., Wernicke, B.P., Farley, K.A., and Dumitru, T.A., 1997, Cenozoic thermal evolution of the central Sierra Nevada, California, from (U-Th)/He thermochronometry: Earth Planetary Science Letters, v.151, 167-179.

Johnson, C., Harbury, N., and Hurford, A.J., 1997, The role of extension in the Miocene denudation of the Nevado-Filábride Complex, Betic cordillera (SE Spain): Tectonics, v.16, 189-204.

Jolivet, M., Brunel, M., Seward, C., Xu, Z., Yang, J., Malavielle, J., Roger, F., Leyreloup, A., Arnaud, N., and $\mathrm{Wu}, \mathrm{C} ., 2$ 2003, Neogene extension and volcanism in the Kunlun Fault zone, northern Tibet: New constraints on the age of the Kunlun Fault, Tectonics, v.22, a1052.

Juez-Larré, J., and Andriessen, P.A.M., 2002, Post Late Paleozoic tectonism in the southern Catalan Coastal Ranges (NE Spain), assessed by apatite fission track analysis: Tectonophysics, v.349, 113-129.

Kalaswad, S., Roden, M.K., Miller, D.S., and Morisawa, M., 1993, Evolution of the continental margin of western India: New evidence from apatite fission-track dating: Journal of Geology, v.101, 667-673.

Kamp, P.J.J., Whitehouse, I.W.S., and Newman, J., 1999, Constraints on the thermal and tectonic evolution of Greymouth coalfield: New Zealand Journal of Geology and Geophysics, v.42, 447-467.

Leech, M.L., and Stockli, D.F., 2000, The late exhumation history of the ultrahigh-pressure Maksyutov complex, south Ural Mountains, from new apatite fission track data: Tectonics, v.19, 153-167.

Lisker, F., and Fachmann, S., 2001, Phanerozoic history of the Mahanadi region, India: Journal of Geophysical Research, v.106, 22027-22050.

Lorencak, M., Seward, D., Vanderhaeghe, O., Teyssier, C., and Burg, J.P., 2001, Low temperature cooling history of the Shuswap metamorphic core complex, British Columbia: constraints from apatite and zircon fission-track ages: Canadian Journal of Earth Sciences, v.38, 1615-1625.

Marsellsea, S.J., Green, P.F., and Webb, J., 2000, Thermal history of the Hodgkinson Province and Laura Basin, Queensland: multiple cooling episodes identified from fission track analysis and vitrinite reflectance data: Australian Journal of Earth Sciences, v.41, 779-799. 
Mathiesen, A., Bidstrup, T., and Christiansen, F., 2000, Denudation and uplift history of the Jameson Land basin, East Greenland - constrained from maturity and apatite fission track data, Global and Planetary Change, v.24, 275-301.

Miller, D.S., and Duddy, I.R., 1989, Early Cretaceous uplift and erosion of the northern Appalachian basin, New York, based on apatite fission track analysis: Earth Planetary Science Letters, v.93, 35-49.

Noble, W.P., Foster, D.A., and Gleadow, A.J.W., 1997, The post-Pan-African thermal and extensional history of crystalline basement rocks in eastern Tanzania: Tectonophysics, v.275, 331-350.

O'Sullivan, P.B., Belton, D.X., and Orr, M., 2000, Post-orogenic thermotectonic history of the Mount Buffalo region, Lachlan Fold Belt, Australia: evidence for Mesozoic to Cenozoic wrench-fault reactivation?: Tectonophysics, v.317, 1-26.

O’Sullivan, P.B., and Currie, L.D., 1996, Thermotectonic history of Mt. Logan, Yukon Territory, Canada: implications of multiple episodes of middle to late Cenozoic denudation: Earth Planetary Science Letters, v.144, 251-261.

O’Sullivan, P.B., Foster, D.A., Kohn, B.P., and Gleadow, A.J.W., 1996, Multiple postorogenic denudation events: An example from the eastern Lachlan fold belt, Australia: Geology, v.24, 563-566.

O’Sullivan, P.B., Hanks, C.L., Wallace, W.K., and Green, P.F., 1995, Multiple episodes of Cenozoic denudation in the northeastern Brooks Range: fission-track data from Okpilak batholith, Alaska: Canadian Journal of Earth Sciences, v.32, 1106-1118.

O’Sullivan, P.B., and Lane, L.S., 1997, Early Tertiary thermotectonic history of the northern Yukon and adjacent Northwest Territories, arctic Canada: Canadian Journal of Earth Sciences, v.34, 1366-1378. O’Sullivan, P.B., Kohn, B.P., and Mitchell, M.M., 1998, Phanerozoic reactivation along a fundamental Proterozoic crustal fault, the Darling River Lineament, Australia: constraints from apatite fission track thermochronology: Earth Planetary Science Letters, v.164, 451-465.

O’Sullivan, P.B., Mitchell, M.M., O’Sulliven, A.J., Kohn, B.P., and Gleadow, A.J.W., 2000, Thermotectonic history of the Bassian Rise, Australia: implications for the breakup of eastern Gondwana along Australia’s southeastern margins: Earth Planetary Science Letters, v.182, 31-47. O’Sullivan, P.B., Murphy, J.M., and Blythe, A.E., 1997, Late Mesozoic and Cenozoic thermotectonic evolution of the central Brooks Range and adjacent North Slope foreland basins, Alaska: Including fission track results from the Trans-Alaska Crustal Transect (TACT): Journal of Geophysical Research, v.102, 20821-20845.

O’Sullivan, P.B., and Wallace, W.K., 2002, Out-of-sequence basement involved structures in the Sadlerochit Mountain region of the Arctic National Wildlife Refuge, Alaska: Evidence and implications from fission-track thermochronology: Bulletin Geological Society America, v.114, 1356-1378.

Omar, G.I., Lutz, T.M., and Giegengack, R., 1994, Apatite fission-track evidence for Laramide and postLaramide uplift and anomalous thermal regime at the Beartooth overthrust, Montana-Wyoming: Bulletin Geological Society America, v.106, 74-85.

Raab, M.J., Brown, R.W., Gallagher, K., Carter, A., and Weber, K., 2002, Late Cretaceous reactivation of major crustal shear zones in northern Namibia: constraints from apatite fission track analysis:

Tectonophysics, v.349, 75-92

Richard, S.M., Smith, C.H., Kimbrough, D.L., Fitzgerald, P.G., Luyendyk, B.P., and McWilliams, M.O., 1994, Cooling history of the northern Ford Ranges, Marie Byrd Land, West Antarctica: Tectonics, v.13, 837-857.

Ring, U., Johnson, C., Hetzel, R., Gessner, K., 2003, Tectonic denudation of a Late Cretaceous-Tertiary collisional belt: Regionally symmetric cooling patterns and their relation to extensional faults in the Anatolide belt of western Turkey: Geological Magazine, v.140, 421-441.

Roden-Tice, M.K., Tice, S.J., and Schofield, I.S., 2000, Evidence for differential unroofing in the Adirondack mountains, New York State, determined by apatite fission-track thermochronology: Journal of Geology, v.108, 155-169.

Roden-Tice, M..K, and Wintsch, R.P., 2002, Early Cretaceous normal faulting in southern New England: Evidence from apatite and zircon fission-track ages: Journal of Geology, v.110, 159-178.

Rohrman, M., van der Beek, P., Andriessen, P., and Cloetingh, S., 1995, Meso-Cenozoic morphotectonic evolution of southern Norway: Neogene domal uplift inferred from apatite fission track thermochronology: Tectonics, v.14, 704-718.

Rohrman, M., van der Beek, P., and Andriessen, P., 1994, Syn-rift thermal structure and post-rift evolution of the Oslo Rift (southeast Norway): New constraints from fission track thermochronology: Earth Planetary Science Letters, v.127, 39-54. 
Sachsenhofer, R.F., Jelen, B., Hasenhuttl, C., Dunkl, I., and Rainer, T., 2001, Thermal history of Tertiary basins in Slovenia (Alpine-Dinaride-Pannonian junction): Tectonophysics, v.334, 77-99.

Sanders, C.A.E., Andriessen, P.A.M., and Cloetingh, S.A.P.L., 1999, Life cycle of the East Carpathian orogen: Erosion history of a doubly vergent critical wedge assessed by fission track thermochronology: Journal of Geophysical Research, v.104, 29095-29112.

Seward, D., Pérez-Estaún, A., and Puchov, V., 1997, Preliminary fission-track results from the southern Urals - Sterliamak to Magnitogorsk: Tectonophysics, v.276, 281-290.

Sobel, E.R., and Dumitru, T.A., 1997, Thrusting and exhumation around the margins of the western Tarim Basin during the India-Asia collision: Journal of Geophysical Research, v.102, 5043-5063.

Sosson, M., Morrillon, A.C., Bourgois, J., Féraud, G., Poupeau, G., and Saint-Marc, P., 1998, Late exhumation stages of the Alpujarride Complex (western Betic Cordilleras, Spain): new thermochronological and structural data on Los Reales and Ojen nappes: Tectonophysics, v.285, 253-273. Spiegel, C., Sachsenhofer, R.F., Privalov, V.A., Zhykalyak, M.V., and Panova, E.A., 2004, Thermotectonic evolution of the Ukrainian Donbas Foldbelt: evidence from zircon and apatite fission track data: Tectonophysics, v.383, 193-215.

Spikings, R.A., Foster, D.A., Kohn, B.P., and O’Sullivan, P.B., 2001, Late Neoproterozoic to Holocene thermal history of the Precambrian Georgetown Inlier, northeast Australia: Australian Journal of Earth Sciences, v.48, 9-24.

Spikings, R.A., Seward, D., Winkler, W., and Ruiz, G.M., 2000, Low-temperature thermochronology of the northern Cordillera Real, Ecuador: Tectonic insights from zircon and apatite fission track analysis:

Tectonics, v.19, 649-668.

Spikings, R.A., Winkler, W., Seward, D., and Handler, R., 2001, Along strike variations in the thermal and tectonic response of the continental Ecuadorian andes to the collision with heterogeneous oceanic crust: Earth Planetary Science Letters, v.186, 57-73.

Steinmann, M., Hungerbühler, D., Seward, D., and Winkler, W., 1999, Neogene tectonic evolution and exhumation of the southern Ecuadorian Andes: a combined stratigraphy and fission-track approach: Tectonophysics, v.307, 255-276.

Thomson, S.N., 1998, Assessing the nature of tectonic contacts using fission-track thermochronology: An example from the Calabrian Arc, southern Italy: Terra Nova, v.10, 32-36.

Thomson, S.N., 2002, Late Cenozoic geomorphic and tectonic evolution of the Patagonian andes between $42^{\circ} \mathrm{S}$ and $46^{\circ} \mathrm{S}$ : An appraisal based on fission-track results from the transpressional intra-arc Liquine-Ofqui fault zone: Bulletin Geological Society America, v.114, 1159-1173.

Thomson, S.N., Hervé, F., and Stöckhert, B., 2001, Mesozoic-Cenozoic denudation history of the Patagonian andes (southern Chile) and its correlation to different subduction processes: Tectonics, v.20, 693-711.

Thomson, S.N., Stöckhert, B., and Brix, M.R., 1998, Thermochronology of high-pressure metamorphic rocks of Crete, Greece: implications for the speed of tectonic processes: Geology, v.26, 259-262.

Thomson, S.N., and Zeh, A., 2000, Fission-track thermochronology of the Ruhla Crystalline Complex: new constraints on the post-Variscan thermal evolution of the NW Saxo-Bohemian Massif: Tectonophysics, v.324, 17-35.

Tseng, H-Y., Burruss, R.C., Onstott, T.C., and Omar, G., 1999, Palaeofluid-flow circulation within a Triassic rift basin evidence from oil inclusions and thermal histories: Bulletin Geological Society America, v.111, 275-290.

Wells, M..L, Snee, L.W., and Blythe, A.E., 2000, Dating of major normal fault systems using thermochronology: an example from the Raft River detachment, Basin and Range, western United States: Journal of Geophysical Research, v.105, 16303-16327.

West, D.P.Jr., and Roden-Tice, M.K., 2003, Late Cretaceous reactivation of the Norumbega fault zone, Maine: Evidence from apatite fission-track ages: Geology, v.31, 649-652.

Zarki-Jakni, B., van der Beek, P., Poupeau, G., Sosson, M., Labrin, E., Rossi, P., and Ferrandini, J., 2004, Cenozoic denudation of Corsica in response to Ligurian and Tyrrhenian extension: Results from apatite fission track thermochronology: Tectonics, v.23, a1003. 